\title{
Determination of the Agricultural Eco-Compensation Standards in Ecological Fragile Poverty Areas Based on Emergy Synthesis
}

\author{
Yang Gao ${ }^{1, *}$, Ziyan Han ${ }^{2}$, Yanzhi Cui ${ }^{3}$, Hanbing Zhang ${ }^{2}$ and Lulu Liu ${ }^{1}$ \\ 1 College of Land Science and Technology, China Agricultural University, Beijing 100193, China; \\ S2018666@cau.edu.cn \\ 2 College of Urban and Environmental Sciences, Peking University, Beijing 100087, China; \\ hanziyan@cau.edu.cn (Z.H.); hbzhang@cau.edu.cn (H.Z.) \\ 3 Sino-Japan Friendship Center for Environmental Protection, Beijing 100029, China; \\ cuiyanzhi@edcmep.org.cn \\ * Correspondence: yanggao@cau.edu.cn; Tel.: +86-10-6273-1988
}

Received: 16 April 2019; Accepted: 29 April 2019; Published: 2 May 2019

\begin{abstract}
Eco-compensation is an important mechanism when applying the theory of ecosystem services to practical development, which translates the external and non-market value of the environment into real financial incentives for local actors. Scientifically formulating feasible and credible compensation standards is the most critical and key step to adjusting the benefits received by environment protectors and beneficiaries. The Inner Mongolia agro-pastoral zone is an important ecological area with an undeveloped economy in Northern China. The implementation of eco-compensation policies contributes to ecological restoration and poverty alleviation. Taking Horqin Left Back Banner, Inner Mongolia, China as a study case, a quantitative model of a non-point source pollution eco-compensation program was established by using emergy synthesis-a thermodynamics-based method in ecological economic systems - to create a comprehensive eco-compensation standard. The results showed that the eco-compensation amounts for non-point source pollution were generally below $10 \%$ of the regional gross domestic product (GDP). A 11-20\% reduction in fertilizer would be accepted according to the field investigation and the optimal eco-compensation strategy reduced the phosphate fertilizer application by $20 \%$ with a compensation standard of $\$ 379.63 /$ ha/year, which was similar to the farmers' willingness to accept compensation. For the accurate creation of a non-point source pollution eco-compensation program, the emergy synthesis overcomes the inconsistency in the quantification of the material flow, ecological flow, and economic flow, guaranteeing the sustainable implementation of non-point source pollution eco-compensation projects.
\end{abstract}

Keywords: ecological compensation; compensation standard; emergy analysis; agro-pastoral zone; Horqin Left Back Banner

\section{Introduction}

Since the 1950s, environmental degradation due to population growth and economic development has gradually attracted attention around the world [1]. Many governments and organizations have tried different projects and policies to mitigate ecological deterioration and resource over-exploitation [2]. Among them, ecological compensation ("eco-compensation" for short) is an essential mechanism for environmental protection and poverty reduction via government-sponsored fiscal payments to ecosystem service providers to maintain certain ecosystem services [3-5]. By encompassing many incentive-based approaches to environmental conservation [6], eco-compensation coordinates interests between shareholders by using public finances [7], and has been widely carried out in the 
United States [8], European Union [9], China [10], and other countries [11]. However, the existing compensation projects also have faced varies challenges, especially in terms of project sustainability [5]. One of the criticisms is that most of the compensation depends on payments and subsidies from the central governments and local governments in the form of cash compensation, especially in the government-dominated protection projects. But many governments have a limited capacity to compensate, since most of the ecological compensation sites are poverty-stricken areas [5]. The high amount of compensation is a serious burden to local governments in economically underdeveloped areas, while simultaneously, too-low payments to beneficiaries will weaken the effect of compensatory projects because of the reduction in the willingness to participate [4]. Therefore, establishing and calculating the compensation standard has become the key to practice, which affects the scientific value and operability of entire eco-compensation projects.

In these existing projects, the eco-compensation standards are often formulated and announced by local or central governments, mainly depending on the actual opportunity cost of providing the services [12]. The European Union initially adopted the opportunity cost method for the compensation for the protection of water resource areas that were lost due to abandoning industrial development [13]. In Costa Rica, the opportunity cost of land was introduced as the compensation standard for upstream land users [14] and the grassland's net income was treated as the opportunity cost and recommended as the compensation standard for farmers' environmental protection [15]. In China, Beijing and Hebei Provinces jointly implemented an eco-compensation program named "Paddy Land-to-Dry Land" to diminishing the interprovincial water conflicts from 2006 to 2016 with an average compensation of $\$ 844 \mathrm{ha}^{-1}$ in 2006 and an increased compensation to $\$ 1031 \mathrm{ha}^{-1}$ in 2008. After the program finished in 2016, Beijing launched a similar program with a compensation standard of $\$ 1313 \mathrm{ha}^{-1}$. But all of the compensation standards are mainly based on the government budgets and opportunity cost. There is also another eco-compensation mode named "Xin'an River pilot project" launched in 2011 in Anhui Province and Zhejiang Province, China, which was similar to the valuation adjustment mechanism. If the annual water quality meets the requirement standards, Zhejiang will pay $\$ 12.5$ million to Anhui, vice versa. Similarly, there is still no lack of legal regulations for such a large amount of compensation. Actually, the compensation standards tend to be greater than the opportunity cost of service providers to provide services in practice [16]. Monetary valuation methods and cost-benefit analysis, represented by the opportunity cost method, often ignore the environmental externalities and limit the decision-making process.

The willingness to pay (WTP)/willingness to accept (WTA) methods are also used to investigate consumers' and the protectors' willingness to pay/accept and evaluate eco-compensation standards, especially in terms of the information that can be derived for policy making [17]. Pan et al. [18] investigated and analyzed people's WTP for the environmental improvement in Min river basin, China. The results showed that rational and equitable standards should be formulated to ensure the great public supervision of the eco-compensation fund. Liu et al. [19] developed a dynamic eco-agriculture compensation standard by coupling famers' WTA and the opportunity cost under multiple scenarios. However, WTP relies heavily on the government fiscal budget, which is always lower than the amount residents are willing to accept, thereby affecting the application of eco-compensation projects. While, WTA is heavily impacted by the farmers' awareness with high uncertainty. The main cause of this dilemma is that traditional monetary accounting, either opportunity cost or the WTP/WTA, cannot scientifically embody the value of ecosystem services. The inconsistency in the methods used to quantify the diverse economic benefits and ecosystem services causes uncertainty in the determination of the eco-compensation standard, so there is a need for building standardized methodological approaches and frameworks to quantify eco-compensation standards.

Emergy is a thermodynamics-based metric defined as "the available solar energy used directly and indirectly to make a service or product" [20]. It is the sum of all energy inputs needed to directly or indirectly produce any product or service [21] that can transfer all the materials and services into one unified unit, solar emergy joules (seJ), using emergy transformity. Using emergy as a common 
evaluation criterion not only reflects the value of human input in the socio-ecosystem, but also the contribution of ecosystem services by integrating economic and ecological sciences. In the field of eco-compensation standard determination, emergy synthesis has been applied to the creation of a water eco-compensation standard to overcome the shortcomings of traditional methods. The accurate quantification of water pollution eco-compensation standard of the Qingyi River showed that emergy synthesis is feasible and accurate [22]. Guo et al. [23] calculated the nitrogen and phosphorus losses in the Yongding River Basin, China using emergy synthesis. Based on emergy synthesis, Guan et al. [24] evaluated the sustainability of Xiaohonghe Basin and proposed an ecological compensation standard for the basin, including the flow of energy, materials, and money. The results of the study suggested that the output based on emergy synthesis would help generate and support new approaches for the long-term environmental protection of the basin and the improvement of the eco-compensation system. Fu et al. [25] provided a framework to calculate the eco-compensation standard for agricultural water and soil conservation based on the emergy synthesis.

The Inner Mongolia agro-pastoral zone is an important ecological zone and an economically poor area in Northern China [26]. In order to improve family income, the local residents' livelihood has gradually shifted from animal husbandry to semi-agricultural and semi-pastoral or agricultural production. However, agricultural production often requires greater fertilizer inputs to maintain crop yields in the agro-pastoral ecozone. With rapid population growth and accelerating development of intensive food production, non-point source pollution of farmland is threatening the local environment and agricultural development [27]. Implementing eco-compensation for the agricultural non-point source pollution control is a good method to prevent environmental pollution and increase farmers' income in such an economically and environmentally fragile region. According to the limitation of the local government payment capacity, it is important to formulate scientific and reasonable eco-compensation standards in order to guarantee the project sustainability in this area.

Here, we address the importance of determining a feasible standard by providing quantitative estimates of the optimal compensation range for preventing the farmland non- point source pollution. In this study, we applied emergy synthesis-a thermodynamics-based method in ecological economic systems-to create a comprehensive eco-compensation standard accounting framework. The scope of our analysis considers the important issue that both the governments' ability to pay and farmers' willingness to accept guarantee the sustainability of the eco-compensation projects implication. We incorporated the willingness of the local farmers to control non-point source pollution by using a conditional value assessment method. Taking the Horqin Left Back Banner (HLBB), a typical poor nation-level county in an agro-pastoral zone, as a case study, we aimed to: (1) establish a quantitative model of non-point source pollution eco-compensation using emergy synthesis, (2) calculate the compensation amount and compare it with the standards of the farmers' willingness to receive compensation, and (3) provide a new scientific approach for the determination of non-point source pollution eco-compensation. There are three sections in this study. First, we begin with material we used, and the building procedure of the quantitative model. Second, we analyze the trends of pollutant emissions in the study area and calculate the eco-compensation standard based on emergy synthesis under different scenarios. Finally, we identify the significance of integrating models and the contribution of this model to the knowledge in preventing the farmland non-point pollution.

\section{Material and Methods}

\subsection{Study Area}

Horqin Left Back Banner (HLBB), Inner Mongolia, China $\left(121^{\circ} 30^{\prime}-123^{\circ} 42^{\prime}\right.$ E, $\left.42^{\circ} 40^{\prime}-43^{\circ} 42^{\prime} \mathrm{N}\right)$ is located in the south-central region of Horqin Sandy Land, has an area of $11,576 \mathrm{~km}^{2}$, and includes 15 towns (Figure 1). It has a temperate continental semi-arid climate. The average annual precipitation is $200-483 \mathrm{~mm}$, and the average annual temperature is $5.8-5.9^{\circ} \mathrm{C}$, which can sustain the growth of dry 
crops. The Eastern part of HLBB is the Liaohe alluvial plain, where the arable land conditions are better. The main crop is spring maize, and its planting area accounts for almost $90 \%$ of all sown areas [28].

HLBB is a typical ecologically sensitive and vulnerable agro-pastoral zone, as well as a poor county in China, suffering from land degradation including desertification, soil salinization, and soil erosion. The demand for food has also increased with increases in the population in HLBB, which has placed tremendous pressure on agricultural development. Farmers have increased the application of chemical fertilizers to increase the yields, and the farmers always apply phosphate fertilizer as the base fertilizer and nitrogen fertilizer as the top application. From 1995 to 2015, the use of chemical fertilizers in HLBB increased from $382.06 \mathrm{~kg} \mathrm{ha}^{-1}$ to $934.20 \mathrm{~kg} \mathrm{ha}^{-1}$. However, the maize yield only increased from $5.37 \mathrm{t} / \mathrm{ha}$ to $5.58 \mathrm{t} / \mathrm{ha}$ during the 20 years. Excessive application of chemical fertilizers did not result in a significant increase in crop yield, but instead produced groundwater pollution and the decline in the quality of cultivated land. In 2017, the local government tried to implement eco-compensation to control the agricultural pollution using the "Implementation Opinions of Inner Mongolia Autonomous Region Government on Implementing the Action Plan for Soil Pollution Prevention and Control" and "Inner Mongolia Autonomous Region Agriculture and Animal Husbandry Modernization 13th Five-Year Development Plan" policies. However, the eco-compensation standards remain undetermined, so scientific measurement and estimation to support government decision-making is urgently needed.

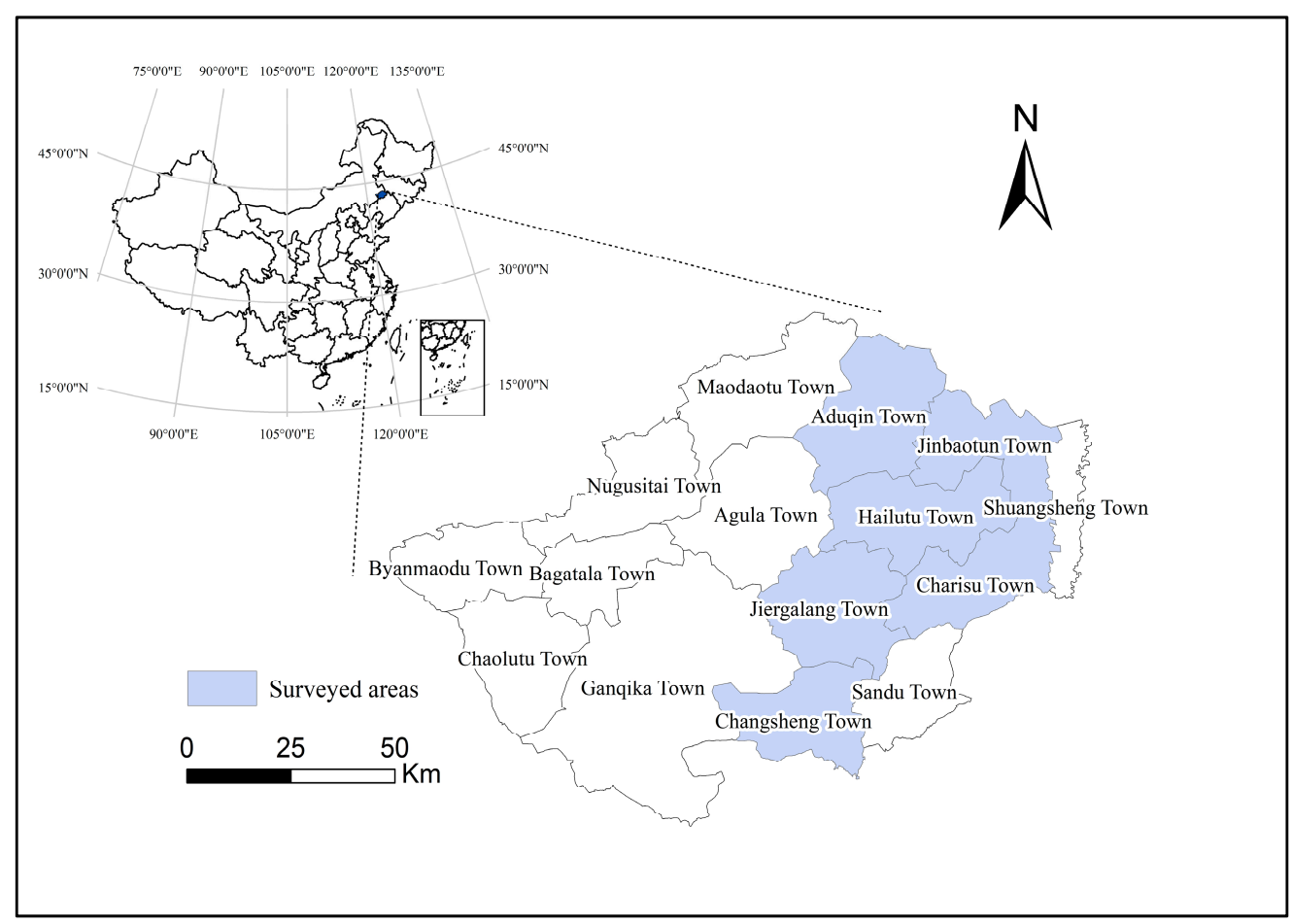

Figure 1. The location of Horqin Left Back Banner (HLBB), Inner Mongolia, China.

\subsection{Materials}

\subsubsection{Field Investigation}

We conducted our 1-month field survey in HLBB in July 2017. Fifteen villages in seven towns were selected using a stratified random sampling method (Figure 1). A total of 135 questionnaires, including questions on the aspects of agricultural fertilizer input, production output, and farmers' awareness and willingness of eco-compensation, were administered by a face-to-face interview for at least $30 \mathrm{~min}$. The questionnaire included personal information, the eco-compensation standard of surveyed farmers' willingness to accept (WTA) to engage in fertilizer reduction application, and the ranges of nitrogen $(\mathrm{N})$ and phosphorus $(\mathrm{P})$ application that farmers are willing to reduce. Ten cards 
with different reduction ranges were presented to the farmers, including 10 choices for fertilizer reduction: $1-10 \%, 11-20 \%, 21-30 \%, 31-40 \%, 41-50 \%, 51-60 \%, 61-70 \%, 71-80 \%, 81-90 \%$, and $91-100 \%$ of the current fertilizer application, and they chose one from amongst them. Based on Schaeffer's sampling formula, the questionnaires were checked, and invalid samples (such as inconsistencies and incomplete information) were removed. A total of 129 valid questionnaires were collected with an effective rate of $95.6 \%$ in the 15 villages.

\subsubsection{Data Acquisition and Processing}

There are four components in our quantitative model, including the calculation of Pollutant emissions amount, calculation of emergy values of pollutant emissions, setting of reduction scenarios, and quantification of eco-compensation standard. In the data collection procedure, the local fertilizer inputs, planting areas, and soil types were collected to estimate the physical amounts generated from the farmland. The pollutant emission coefficient was used to estimate the pollutant emission from the farmland to the surrounding areas caused the environment pollution.

The data of fertilizer inputs and planting areas were obtained from the Statistical Yearbook of Horqin Left Back Banner in Inner Mongolia $(1995,2000,2015)$. The pollutant emission coefficient of $\mathrm{N}_{2} \mathrm{O}$ or $\mathrm{NH}_{3}$ were obtained from the First National Census of Pollution Sources in China. The HLBB soil data were extracted from the Harmonized World Soil Database. The boundary of administrative districts in HLBB were gained from the Resource and Environment Data Cloud Platform.

\subsection{Methodology}

The losses of $\mathrm{N}$ and $\mathrm{P}$ are the main reason for agricultural non-point source pollution, which aggravate greenhouse gas (GHG) emissions, groundwater pollution, water eutrophication, and soil eutrophication. Based on emergy synthesis, the quantification of an agricultural non-point source pollution eco-compensation standard needs to determine the ecological economic value of the reduced $\mathrm{N}$ and $\mathrm{P}$ pollutant emission and the loss of maize yields as the ecological compensation quantity.

\subsubsection{Calculation of the Pollutant Emissions Amount}

Quantification of agricultural non-point source pollution is the basis of ecological compensation standard determination. In this paper, we identified the five main pollutants in the local farmland: ammonia $\left(\mathrm{NH}_{3}\right)$, nitrous oxide $\left(\mathrm{N}_{2} \mathrm{O}\right)$, ammonia nitrogen $\left(\mathrm{NH}_{3}-\mathrm{N}\right)$, total nitrogen $(\mathrm{TN})$, and total phosphorus (TP). $\mathrm{NH}_{3}$ is the largest source of pollutant emissions in China and $53.53 \%$ of the total $\mathrm{NH}_{3}$ emissions are caused by agricultural chemical fertilizer inputs. $\mathrm{N}_{2} \mathrm{O}$ emission is also recognized as the most common agricultural source of global GHG. N and P in agricultural chemical fertilizers application enter water bodies through surface runoff and underground leaching, resulting in water quality degradation and eutrophication. According to the "Pollutant Emission List" and the "First National Census of Pollution Sources in China", $\mathrm{NH}_{3}-\mathrm{N}, \mathrm{TN}$, and TP were selected as the indices of non-point source pollution in water.

The physical amounts of $\mathrm{N}_{2} \mathrm{O}$ and $\mathrm{NH}_{3}$ pollutants emission in different fertilizer input levels were calculated using the emission coefficient method. The formula is as follows:

$$
E_{j, q}=N_{p, q} \times f_{j}
$$

where $E_{j, q}$ is the physical emission of pollutant $j\left(\mathrm{~kg} \mathrm{ha}^{-1}\right)$ in the fertilizer input scenario $q ; j$ is the pollutant type, $\mathrm{N}_{2} \mathrm{O}$ or $\mathrm{NH}_{3} ; N_{p, q}$ is the application amount of nitrogen fertilizer $\left(\mathrm{kg} \mathrm{ha}^{-1}\right)$ in the fertilizer input scenario $q$; and $f_{j}$ is the pollutant emission coefficient, which are obtained from the First National Census of Pollution Sources in China.

The physical emission amounts of $\mathrm{NH}_{3}-\mathrm{N}, \mathrm{TN}$, and TP were calculated using the source strength coefficient method. The formula is:

$$
E_{m, q}=I_{m, q} \times \omega \times A,
$$


where $E_{m, q}$ is the amount of pollutant $m$ emission in water generated for agriculture $\left(\mathrm{kg} \mathrm{ha}^{-1}\right)$ in the fertilizer input scenario $q ; m$ is the type of pollutant, including $\mathrm{NH}_{3}-\mathrm{N}$, TN, or TP; and $A$ is the planting area of spring maize $\left(10^{3} \mathrm{ha}\right)$. The data were obtained from the Statistical Yearbook of Horqin Banner in Inner Mongolia. $\omega$ is the loss coefficient of farmland according to an empirical formula, which was 0.05 for maize fields and $I_{m, q}$ is the pollutant source intensity coefficient of pollutant $m\left(\mathrm{~kg} \mathrm{ha}^{-1}\right)$ in the fertilizer input scenario $q$. Based on the Guideline for Chinese environmental and economic accounting and technology, the source intensity coefficients of $\mathrm{NH}_{3}-\mathrm{N}, \mathrm{TN}$, and TP then need to be revised according to the soil type, fertilizer application structure, and rainfall amount. The correction formula is as follows:

$$
I_{m, q}=I S_{m} \times s o \times f_{q} \times f s_{q} \times P,
$$

where $I S_{m}$ is the standard source coefficient of the pollutant $m$. The "China Environmental and Economic Accounting Series" indicates that the standard farmland source coefficients $\left(I S_{m}\right)$ are 30, 47.4, and $15.9 \mathrm{~kg} \mathrm{ha}^{-1}$ for $\mathrm{NH}_{3}-\mathrm{N}, \mathrm{TN}$, and TP, respectively. so is the correction factor for soil type, $P$ is the correction factor for rainfall, $f_{q}$ is the correction factor for fertilizer application in the fertilizer input scenario $q$, and $f s_{q}$ is the structural correction factor for chemical fertilizer application in the fertilizer input scenario $q$.

The farmland soil can be divided into sandy, loam, and clay, with the corresponding correction coefficients (so) of 0.8-1.0, 1.0, and 0.6-0.8. The correction coefficient of rainfall is $0.6-1.0$ when the annual rainfall is below $400 \mathrm{~mm}$, the coefficient is 1.0-1.2 when between 400 and $800 \mathrm{~mm}$, and the correction coefficient is $1.2-1.5$ when more than $800 \mathrm{~mm}$. The annual precipitation in HLBB is approximately $200-483 \mathrm{~mm}$. Therefore, $p$ was set to 1.0 . The correction factors of fertilizer application $\left(f_{q}\right)$ and structure $\left(f_{s_{q}}\right)$ in the fertilizer inputs scenario are listed in Tables 1 and 2.

Table 1. Correction factor of fertilizer application under various fertilizer inputs. $Q$ is the fertilizer application amount.

\begin{tabular}{ccccccc}
\hline$Q$ (kg ha $^{-1}$.year) & $Q \geq \mathbf{2 . 3}$ & $\mathbf{2 . 3}>Q \geq \mathbf{2 . 0}$ & $\mathbf{2 . 0}>Q \geq \mathbf{1 . 7}$ & $\mathbf{1 . 7}>Q \geq \mathbf{1 . 3}$ & $\mathbf{1 . 3}>Q \geq \mathbf{1 . 0}$ & $Q<\mathbf{1 . 0}$ \\
\hline$f$ & 1.4 & 1.2 & 1.1 & 1 & 0.9 & 0.8 \\
\hline
\end{tabular}

Table 2. Correction factor of fertilizer application structure under various fertilizer inputs. $R$ is the nitrogen fertilizer application ratio.

\begin{tabular}{cccccc}
\hline $\boldsymbol{R}(\mathbf{\%})$ & $\boldsymbol{R} \geq \mathbf{5 0}$ & $\mathbf{5 0}>\boldsymbol{R} \geq \mathbf{4 5}$ & $\mathbf{4 5}>\boldsymbol{R} \geq \mathbf{4 0}$ & $\mathbf{4 0}>\boldsymbol{R} \geq \mathbf{3 5}$ & $\mathbf{R}<\mathbf{3 5}$ \\
\hline$f_{s}$ & 1.4 & 1.3 & 1.2 & 1.1 & 1.0 \\
\hline
\end{tabular}

\subsubsection{Calculation of Emergy Values of Pollutant Emissions}

Emergy theory uses solar energy as a benchmark and converts different types of incomparable values or products into a unified emergy unit via emergy transfermity [29]. Emergy transfers different resources or services generated through different processes to a common basis, regardless if these resources have a market or not. From a view of the complete system to identify and measure its flows and inventories, emergy synthesis is a top-down approach to convert those values into emergy flows and finally use as integrated indicators of thermodynamic performance the ratios between the aggregate flows of emergy [30,31]. In this study, the general idea of quantifying farmland eco-compensation standards based on emergy synthesis is to use the ecological energy value of pollutants as the eco-compensation for pollution. The main steps are as follows:

$$
E M_{n, q}=E E R_{n} \times E_{n, q}
$$

where $E M_{n, q}$ is emergy (seJ) of pollution $n$ emission in the fertilizer input scenario $q$, including $\mathrm{NH}_{3}$, $\mathrm{N}_{2} \mathrm{O}, \mathrm{NH}_{3}-\mathrm{N}, \mathrm{TN}$, and TP; $E E R_{n}$ is emergy transformity of pollution $n$ (seJ/g or seJ/J); and $E_{n, q}$ is the 
amount of pollutant $m$ emission ( $\mathrm{g}$ or $\mathrm{J}$ ) in the fertilizer input scenario $q$. When the pollutant is $\mathrm{N}_{2} \mathrm{O}$ or $\mathrm{NH}_{3}, E_{n, q}$ is the $E_{j, q}$ calculated above. When the pollutant is $\mathrm{NH}_{3}-\mathrm{N}$, TN, or TP, $E_{n, q}$ is the $E_{m, q}$ calculated above. The global emergy baseline applied in this study is $15.83 \times 10^{24} \mathrm{seJ} / \mathrm{year}$ [32].

\subsubsection{Setting of Reduction Scenarios and Different Fertilizers Reduction Proportions}

Five reduction scenarios and three different fertilizers reduction proportions were constructed (Table 3). In scenarios 1-5, the range in fertilizer reductions varied from $10 \%$ to $50 \%$. In scenario 1 , the fertilizer reduction was $10 \%$. In scenario 2 , the fertilizer reduction was $20 \%$, and so on. In setting the nitrogen and phosphate reduction proportions, NPR refers to the reduction in nitrogen and phosphate fertilizer application in the same proportion. In the Nitrogen Fertilizer Reduction (NR) setting, the phosphate fertilizer remained unchanged and all reductions were nitrogen fertilizer reduction. In the Phosphate Fertilizer Reduction (PR) setting, nitrogen fertilizer remained unchanged, and all reductions were that of phosphate fertilizer.

Table 3. Different reduction of fertilizer application scenarios.

\begin{tabular}{ccccccc}
\hline \multirow{2}{*}{$\begin{array}{c}\text { Fertilizer } \\
\text { Reduction Scenario }\end{array}$} & \multicolumn{3}{c}{ Reduction Proportion of Nitrogen and Phosphate Fertilizer (\%) } \\
\cline { 2 - 7 } & $\begin{array}{c}\text { Nitrogen and Phosphate } \\
\text { Fertilizer Reduction } \\
\text { (NPR) }\end{array}$ & $\begin{array}{c}\text { Nitrogen Fertilizer } \\
\text { Reduction } \\
\text { (NR) }\end{array}$ & $\begin{array}{c}\text { Phosphate Fertilizer } \\
\text { Reduction } \\
\text { (PR) }\end{array}$ \\
\cline { 2 - 8 } & $\mathbf{N}$ & $\mathbf{P}$ & $\mathbf{N}$ & $\mathbf{P}$ & $\mathbf{N}$ & $\mathbf{P}$ \\
\hline $\mathbf{1}$ & -10 & -10 & -20 & - & - & -20 \\
$\mathbf{2}$ & -20 & -20 & -40 & - & - & -40 \\
$\mathbf{3}$ & -30 & -30 & -60 & - & - & -60 \\
$\mathbf{4}$ & -40 & -40 & -80 & - & - & -80 \\
$\mathbf{5}$ & -50 & -50 & -100 & - & - & -100 \\
\hline
\end{tabular}

\subsubsection{Quantification of Eco-Compensation Standard Based on Emergy Synthesis}

To create a compensation standard under different fertilizer reduction scenarios based on emergy synthesis, we regarded the ecological economic values of reduced pollutant emissions and yield loss as the agricultural non-point source eco-compensation standard. In the existing fertilizer input level in HLBB, $E M_{n, q}$ is represented by $\overline{E M_{n}}$. The calculation formula of the ecological-economic values of reduced pollutant emissions is as follows:

$$
C_{q}=\sum_{n}^{5} \sum\left(\overline{E M}_{n}-E M_{n, q}\right) / E D R,
$$

where $C_{q}$ is the ecological economic value of reduced pollutant emissions $(\$ / \mathrm{ha})$ in the fertilizer reduction scenario $q ; E D R$ is the emergy currency ratio (sej/\$), which refers to the ratio of the total emergy used in the country (or region) to the country or region's gross domestic product (GDP) for that year. The lower the value, the better the economic benefit. $\overline{E M_{n}}$ is the current emergy (seJ) of pollution $n$ emission in the existing fertilizer input level and $E M_{n, q}$ is the emergy (seJ) of pollution $n$ emission under the fertilizer reduction scenario $q$.

The calculation formula of the ecological-economic value of yield loss due to fertilizer reduction is as follows:

$$
M_{q}=\left(\bar{Y}-Y_{q}\right) \times E E R_{m} / E D R,
$$

where $M_{q}$ is the ecological-economic value of yield loss ( $\$ /$ ha) due to the reduction in maize yield in the fertilizer reduction scenario $q ; \bar{Y}$ is the average annual yields of maize $\left(\mathrm{kg} \mathrm{ha}^{-1}\right)$ in HLBB; $E E R_{m}$ is the transformity of maize; and $Y_{q}$ is the yield of maize $\left(\mathrm{kg} \mathrm{ha}^{-1}\right)$ in the fertilizer reduction scenario $q$. In general, the appropriate fertilizer input increases maize yields, whereas excessive or insufficient application reduces the yields. A field experiment was conducted in Horqin Sandy Land to determine the relationship between fertilizer application and the yields of maize. When the relative soil water 
content is at the optimal state of $67.2 \%$, the relationship between the fertilizer input and the yield of maize is as follows [33]:

$$
\begin{gathered}
Y_{q}=\left(5.169048+0.4267 \times\left(\frac{x_{1}}{15}-3\right)+0.106951 \times\left(\frac{x_{2}}{10}-3.6\right)-0.415\right. \\
\left.\times\left(\frac{x_{1}}{15}-3\right)^{2}-0.002 \times\left(\frac{x_{2}}{10}-3.6\right)^{2}-0.215 \times\left(\frac{x_{1}}{15}-3\right) \times\left(\frac{x_{2}}{10}-3.6\right)\right) \times 2500
\end{gathered}
$$

where $Y_{q}$ is the maize yield $\left(\mathrm{kg} \mathrm{ha}^{-1}\right)$ in fertilizer reduction scenario $q$ and $x_{1}$ and 2 are the input of nitrogen fertilizer $\left(\mathrm{g} / \mathrm{m}^{2}\right)$ and phosphate fertilizer $\left(\mathrm{g} / \mathrm{m}^{2}\right)$ under the fertilizer reduction scenario $q$, respectively. According to the field investigation, the average application of nitrogen fertilizer is approximately $30 \mathrm{~g} / \mathrm{m}^{2}$, and the average application of phosphate fertilizer is approximately $45 \mathrm{~g} / \mathrm{m}^{2}$, resulting in actual maize yields of 10,000-12,000 $\mathrm{kg} \mathrm{ha}^{-1}$ in which the soil moisture is in the optimum condition in HLBB. Using the formula above to estimate yields of spring maize in HLBB, the results was $11,538.71 \mathrm{~kg} \mathrm{ha}^{-1}$. The simulation results of this estimation were close to the actual yield and reliable. Therefore, we used this formula to predict the maize yield $\left(Y_{q}\right)$ under different fertilizer reduction scenarios. Finally, the whole eco-compensation standard was calculated as follows:

$$
E_{q}=C_{q}+M_{q}
$$

where $E_{q}$ is the eco-compensation standard for agricultural non-point source pollution control, which contains the ecological economic value of reduced pollutant emissions and the yield loss due to the fertilizer reduction.

\section{Results}

\subsection{Trends in Major Agricultural Pollutant Emissions in HLBB 1995-2015}

Based on the calculation of the physical pollutant amounts, Table 4 shows the main agricultural pollutant emissions in HLBB from 1995 to 2015. The agricultural non-point source pollution has gradually intensified in HLBB since 1995. The pollutant emission amounts follow the order: $\mathrm{NH}_{3}>$ $\mathrm{N}_{2} \mathrm{O}>\mathrm{TN}>\mathrm{NH}_{3}-\mathrm{N}>$ TP. The emission amounts of $\mathrm{N}_{2} \mathrm{O}$ and $\mathrm{NH}_{3}$ gradually increased over time, while $\mathrm{NH}_{3}-\mathrm{N}$, TN, and TP amounts fluctuated. The amount of $\mathrm{NH}_{3}$ emissions increased obviously over the 20 years, occupying the greatest proportion of all emissions. However, from the perspective of the emergy value, the increase in $\mathrm{N}_{2} \mathrm{O}$ emission occupied the largest proportion, reaching $58.28 \%$ in 2015. The calculation result of $\mathrm{N}_{2} \mathrm{O}$ based on emergy synthesis is much bigger than the physical amount, which shows that, compared with the physical amount, the emission of $\mathrm{N}_{2} \mathrm{O}$ will produce more economic, social, and environmental impacts, which are considered synthetically by the emergy synthesis. The environmental impacts of $\mathrm{N}_{2} \mathrm{O}$ emissions dominated the over other pollutants over time.

\begin{tabular}{|c|c|c|c|c|c|c|}
\hline \multirow{2}{*}{$\begin{array}{l}\text { Pollutant } \\
\text { Emission }\end{array}$} & \multicolumn{3}{|c|}{ Raw Amount (kg ha-1/year) } & \multicolumn{3}{|c|}{ Emergy Value (seJ/ha/year) } \\
\hline & 1995 & 2005 & 2015 & 1995 & 2005 & 2015 \\
\hline $\mathrm{N}_{2} \mathrm{O}$ & 2.02 & 1.49 & 5.97 & $\begin{array}{c}2.29 \times 10^{14} \\
(27.19 \%)\end{array}$ & $\begin{array}{c}1.69 \times 10^{14} \\
(34.68 \%)\end{array}$ & $\begin{array}{c}6.76 \times 10^{14} \\
(58.28 \%)\end{array}$ \\
\hline $\mathrm{NH}_{3}$ & 14.15 & 10.46 & 41.8 & $\begin{array}{c}6.40 \times 10^{12} \\
(0.76 \%)\end{array}$ & $\begin{array}{c}4.73 \times 10^{12} \\
(0.97 \%)\end{array}$ & $\begin{array}{c}1.89 \times 10^{13} \\
(1.63 \%)\end{array}$ \\
\hline $\mathrm{NH}_{3}-\mathrm{N}$ & 2.41 & 1.24 & 1.85 & $\begin{array}{c}1.41 \times 10^{14} \\
(16.71 \%)\end{array}$ & $\begin{array}{c}7.23 \times 10^{13} \\
(14.86 \%)\end{array}$ & $\begin{array}{c}1.08 \times 10^{14} \\
(9.30 \%)\end{array}$ \\
\hline $\mathrm{TN}$ & 3.8 & 1.97 & 2.92 & $\begin{array}{c}2.22 \times 10^{14} \\
(26.43 \%)\end{array}$ & $\begin{array}{c}1.15 \times 10^{14} \\
(23.70 \%)\end{array}$ & $\begin{array}{c}1.71 \times 10^{14} \\
(14.73 \%)\end{array}$ \\
\hline $\mathrm{TP}$ & 1.28 & 0.66 & 0.98 & $\begin{array}{c}2.43 \times 10^{14} \\
(28.92 \%)\end{array}$ & $\begin{array}{c}1.25 \times 10^{14} \\
(25.78 \%)\end{array}$ & $\begin{array}{c}1.86 \times 10^{14} \\
(16.06 \%)\end{array}$ \\
\hline
\end{tabular}

Table 4. Emissions trends of main agricultural pollutants per area in Horqin Left Back Banner (HLBB) from 1995 to 2015.

Note: the underlined number refers to the maximum value. 


\subsection{Eco-Compensation Standard of Farmers' WTA}

According to our field investigation, the age of surveyed farmers ranged from 25 to 80 years old, mainly concentrated between 35 and 55 years old, which accounted for $58.2 \%$ of the sample. Men are the main labor force for agricultural production, accounting for $89.1 \%$ of the sample. Most respondents have a low level of education, and $81.4 \%$ of them only have primary or junior high school education. Most of the respondents had expertise in planting, and $51.9 \%$ of respondents had experience in planting for more than 20 years. The cultivated land of each household was no less than one ha. Overall, $69.8 \%$ of farmers were willing to reduce fertilizer application, and more than $60 \%$ of the farmers indicated that they could accept a fertilizer application reduction of no more than $40 \%$ (Table 5). They thought that this reduction range was acceptable, and that eco-compensation could be used to compensate for the loss of income caused by yield reduction. In terms of compensation form, most of the farmers (56.7\%) preferred cash compensation; technical compensations, such as planting training and increasing crop prices, were also preferred $(27.6 \%)$. With regard to the eco-compensation standard, nearly everyone stated that the lowest acceptable compensation standard is the direct loss of agricultural income. The acceptable amount of eco-compensation ranged from 32.11-1364.72 \$/ha. Overall, with the increase in fertilizer reduction ratio, the willingness to accept eco-compensation gradually increased.

Table 5. Farmers' willingness to reduce the usage of chemical fertilizers in Horqin Left Back Banner (HLBB).

\begin{tabular}{|c|c|c|c|c|c|c|c|}
\hline \multirow{3}{*}{$\begin{array}{l}\text { Fertilizer } \\
\text { Application } \\
\text { Reduction } \\
\text { Range (\%) }\end{array}$} & \multirow{3}{*}{$\begin{array}{c}\text { Proportion } \\
\quad(\%)\end{array}$} & \multicolumn{6}{|c|}{ Compensation Standard of Farmer's Willingness to Accept } \\
\hline & & \multicolumn{2}{|c|}{ Mean } & \multicolumn{2}{|c|}{ Max. } & \multicolumn{2}{|c|}{ Min. } \\
\hline & & CNY/ha/year & \$/ha/year & CNY/ha/year & \$/ha/year & CNY/ha/year & \$/ha/year \\
\hline $1-10$ & 5.43 & 200.00 & 32.11 & 800 & 128.44 & 0 & 0 \\
\hline $11-20$ & 30.23 & 1223.50 & 196.44 & 4000 & 642.22 & 0 & 0 \\
\hline $21-30$ & 14.73 & 2150.50 & 345.27 & 5500 & 883.05 & 0 & 0 \\
\hline $31-40$ & 13.18 & 3300.00 & 529.83 & 7500 & 1204.16 & 1000 & 160.55 \\
\hline $41-50$ & 18.60 & 3555.50 & 570.85 & 7000 & 1123.88 & 800 & 128.44 \\
\hline $51-60$ & 12.40 & 3500.00 & 561.94 & 5000 & 802.77 & 2000 & 321.11 \\
\hline $61-70$ & 0.78 & 3500.00 & 561.94 & 8000 & 1284.44 & 3500 & 561.94 \\
\hline $71-80$ & 0.00 & - & - & - & - & - & - \\
\hline $81-90$ & 0.00 & - & - & - & - & - & - \\
\hline 91-100 & 4.65 & 8500.00 & 1364.72 & 15,000 & 2408.32 & 5000 & 802.77 \\
\hline
\end{tabular}

\subsection{Eco-Compensation Standard Based on Emergy Synthesis Under Current and Reduction Scenarios}

Under the current and these different fertilizer reduction scenarios in HLBB, the physical amounts and emergy values of the pollutant emissions and simulated maize yields were obtained using emergy synthesis (Tables A1-A4). Then, eco-compensation standards for pollutant emission reduction and maize yield loss were calculated based on the differences between the current and fertilizer reduction scenarios (Tables A5 and A6). According to the results, the eco-compensation standard gradually increases as the proportion of fertilizer application reduction increases (Table A7, Figure 2). When the proportion is $20 \%$, farmers should be compensated with $\$ 379.63-660.62 /$ ha/year. When the proportion of the fertilizer reduction reached $100 \%$, the farmers should be compensated with \$1919.04-5028.53/ha/year. Compared with the reduction in nitrogen fertilizer or reduction of both nitrogen and phosphate fertilizer, the reduction of only phosphate fertilizer produces a more favorable result with the lowest eco-compensation standard when the farmers reduce the same proportions of both fertilizers. Among these scenarios, the reduction of nitrogen fertilizer application requires the highest amount of eco-compensation. In general, phosphate fertilizer performs well in increasing maize yield, but produces different effects in sandy areas. In sandy areas, the application of nitrogen fertilizer plays a leading role in maize yield, and the low soil organic matter content means the applied phosphate fertilizer is not well absorbed by the crop in HLBB [33]. 


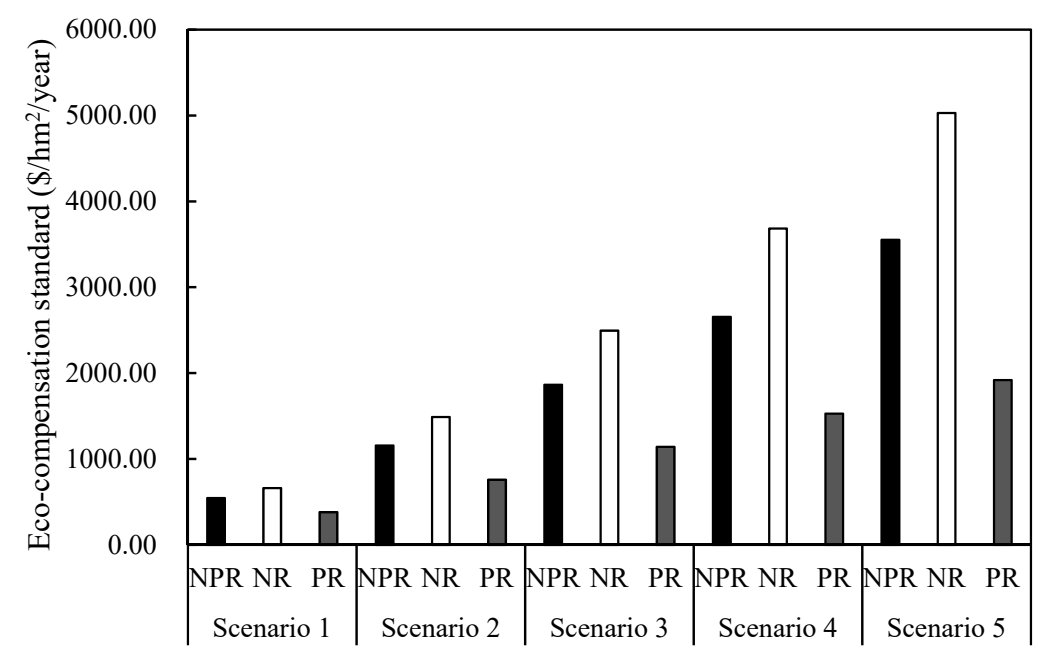

Figure 2. The eco-compensation of agricultural non-point pollution control for different scenarios.

According to the field investigation, $30 \%$ of the farmers indicated that they would accept a $10-20 \%$ reduction in fertilizer application. According to the simulation results, the optimal eco-compensation strategy is a $20 \%$ reduction in phosphate fertilizer application with a compensation standard of $\$ 379.63 /$ ha/year. This standard is similar to the average of farmer's WTA (\$345.27/ha/year) in the reduction proportion range of 21 to $30 \%$, and lower than the average of farmer's WTA (\$529.83/ha/year) in the reduction range of 31 to $40 \%$. From the perspective of regional economic development, the non-point source pollution eco-compensation standard accounts for 6.04\% of GDP per capita (\$6285.40 per capita) in HLBB in 2015. The maize planting area was 166,597 ha in 2015 in HLBB, and the compensation amount would be about $\$ 63.25$ million if this compensation standard was implemented across the whole county, which would account for $2.72 \%$ of the regional GDP (\$2327.17 million) in HLBB.

\section{Discussion}

\subsection{Significance of Integrating Models and the Novelty of the Emergy-Based Eco-Compensation Standard Accounting}

Unlike the ecological restoration of natural ecosystems, eco-compensation projects must respect the interests of local stakeholders in the long-term sustainable implementation, not only the ecological conservation effects. Because the local government plays a key role in the prevention of non-point source pollution from farmland, a compensation standard that suits the local financial situation is critical to eco-compensation implementation. Currently, the determination of eco-compensation standards is mainly based on the economic methods, such as market value method and the WTA method. But due to the complexity of ecosystem, the limitations of economic methods conducted a heated debate on the suitability and feasibility. Being a theory representing both the environmental values and economic values with a common measure, emergy synthesis can comprehensively determine the appropriate non-point source pollution eco-compensation amount, overcoming the randomness of human preferences. The creation of an eco-compensation standard based on emergy synthesis is quick and clear, which can synthetically reflect the material flow, energy flow, and economic flow in the prevention of non-point source pollution from farmland. It is a unified approach that is accessible and feasible and could be applied by local stakeholders and policymakers.

In the implementation process of eco-compensation project in poverty-stricken areas, the significance of using integrating models is to establish a standard reflecting the real benefits stakeholders will receive from doing so, and to shape a better mechanism to keep the low-income farmers involve in these initiatives for a long-term [34]. Compared with the integrated model, a single method is prone to bias and low-robust, especially in the social ecological complex systems. In this study, we used the emergy synthesis to estimate the agricultural eco-compensation standard, as well as 
the WTA as a reference. We attempt to establish an equitable standard that takes into account regional developments and the willingness of the residents, which can help ensure that eco-compensation does not become a cause for resource appropriation that dispossesses low-income farmers, as well as that does not become a heavy financial burden on the local government.

Additionally, the use of emergy synthesis to calculate farmland non-point source pollution can give some support to the environment tax determination. As mentioned above, the input of nitrogen and phosphate fertilizer will lead to the pollutant emission, i.e., $\mathrm{NH}_{3}, \mathrm{~N}_{2} \mathrm{O}, \mathrm{NH}_{3}-\mathrm{N}$, TN, TP. As far as it goes, emergy input of fertilizer will cause the emergy out of pollutant emission. According to the environmental economics theory, products produced with pollutants should be taxed due to the negative externalities they cause. So we defined an index to present this pollutant emission environmental load ratio by the ratio of the emergy input and output in the planting procedure as follows:

$$
E L=\sum_{n}^{5} E_{n} / E F \times 100 \%
$$

where $E L$ is the pollutant emission environmental load ratio of fertilizer input; $E_{n}$ is the emergy (seJ) of pollution $n$ emission under the fertilizer input; $E F$ is the emergy (seJ) of the fertilizer input. According to the emergy-based calculation results, the pollutant emission environmental load ratio of fertilizer application is approximately $14.87 \%$ in HLBB in 2015. This ratio can be used as a reference for the determination of pollution emission taxes. In 2015, the fertilizer cost of maize planting was about $\$ 282 /$ ha/year in Inner Mongolia, China [35]. The cost will increase by $\$ 41 /$ ha/year if it is charged to reduce the incentive of the consumption and production of fertilizer. Of course, tax rate setting is a very complicated issue, and this is only a rough estimate. More detailed and accurate estimation should be based on a path towards both large-scale field trials and other theoretical synthesis.

\subsection{Contribution to the Knowledge in Preventing the Farmland Non-Point Pollution}

Until now, there was no national-level eco-compensation legislation in China, and the practice of eco-compensation has mainly depended on local administrative regulations, government documents, and intergovernmental agreements. A carefully designed eco-agriculture compensation standard is crucial for rural sustainable development [31], especially in poverty-stricken areas that experience economic and ecological fragility. Studies have shown that eco-compensation is an effective governmental poverty reduction tool by providing compensatory payments to the poor [36]. However, most ecological compensation projects require the jointly financial supporting from central government and local governments in China. The limited budgets of local governments in poor areas restrict the implementation of eco-compensation projects. By collecting the results obtained from other studies, we compared the recommended compensation standard with the proportion of total eco-compensation amount to regional GDP (Table 6). The results show that the eco-compensation standards for non-point source pollution in farmland in different regions are generally below $10 \%$ of the regional GDP, even though the determination methods are different. In areas with more developed economies, recommended eco-compensation standard is higher, while the burden of implementing eco-compensation policies on local finances is smaller. Economically developed areas have the financial capacity to carry out a large amount of ecological compensation investment within the budget, but in less developed areas, although the proportion of investment has already accounted for a higher proportion of local GDP, the total amount of compensation is limited. The recommended eco-compensation standard in HLBB is approximately consistent with that of other developing regions, and its proportion to local GDP is $2.72 \%$, higher than that of developed areas. From the perspective of promoting the development of poverty-stricken areas and alleviating poverty, the investment of eco-compensation in underdeveloped areas, such as HLBB, still cause a more serious burden than that in developed regions, although the eco-compensation standards are coincident. The jointly supporting from local finance and central finance are required in the implementation of the eco-compensation. 
Table 6. Methods of compensation for different targets.

\begin{tabular}{|c|c|c|c|c|c|c|c|c|}
\hline \multirow[t]{2}{*}{ Methods } & \multirow[t]{2}{*}{ Goal } & \multirow[t]{2}{*}{ Year } & \multicolumn{2}{|c|}{$\begin{array}{l}\text { Recommended Eco-Compensation } \\
\text { Standard }\end{array}$} & \multirow{2}{*}{$\begin{array}{l}\text { Proportion of Total } \\
\text { Eco-Compensation Amount } \\
\text { to Regional GDP (\%) }\end{array}$} & \multirow[t]{2}{*}{ Location } & \multirow{2}{*}{$\begin{array}{l}\text { Regional } \\
\text { Economic } \\
\text { Situation }\end{array}$} & \multirow[t]{2}{*}{ References } \\
\hline & & & $\mathrm{CNY} / \mathrm{ha}$ & \$/ha & & & & \\
\hline $\begin{array}{l}\text { Emergy } \\
\text { Synthesis }\end{array}$ & $\begin{array}{c}\text { Prevention of } \\
\text { non-point source } \\
\text { pollution in farmland }\end{array}$ & 2015 & 2364.91 & 379.63 & 2.72 & $\begin{array}{l}\text { Horqin Left } \\
\text { Back Banner, } \\
\text { China }\end{array}$ & Developing & This research \\
\hline $\begin{array}{l}\text { Willingness to } \\
\text { accept }\end{array}$ & Eco-fallow & 2015 & 1520 & 244 & 1.01 & $\begin{array}{l}\text { Three Gorges } \\
\text { Reservoir Area, } \\
\text { China }\end{array}$ & Developing & $\begin{array}{c}\text { Yin et al., } 2017 \\
\text { [37] }\end{array}$ \\
\hline $\begin{array}{l}\text { Willingness to } \\
\text { accept }\end{array}$ & $\begin{array}{c}\text { Prevention of } \\
\text { non-point source } \\
\text { pollution in farmland }\end{array}$ & 2014 & $1130-9190$ & $181-1480$ & $0.37-2.98$ & $\begin{array}{l}\text { Macheng City, } \\
\text { Hubei Province, } \\
\text { China }\end{array}$ & Developed & $\begin{array}{c}\text { Yu et al., } 2015 \\
{[38]}\end{array}$ \\
\hline $\begin{array}{l}\text { Willingness to } \\
\text { accept }\end{array}$ & $\begin{array}{c}\text { Prevention of } \\
\text { non-point source } \\
\text { pollution in farmland }\end{array}$ & 2013 & $4750-12,400$ & 763-1990 & $6.10-15.91$ & $\begin{array}{c}\text { Jingshan } \\
\text { County, Hubei } \\
\text { Province, China }\end{array}$ & Developing & $\begin{array}{c}\text { Yu et al., } 2015 \\
\text { [38] }\end{array}$ \\
\hline $\begin{array}{l}\text { Emergy } \\
\text { Synthesis }\end{array}$ & $\begin{array}{l}\text { Returning farmland } \\
\text { to lake }\end{array}$ & 2010 & 865,000 & 139,000 & 7.51 & $\begin{array}{l}\text { Dongting Lake } \\
\text { Region, China }\end{array}$ & Developing & $\begin{array}{c}\text { Mao et al., } 2014 \\
\text { [39] }\end{array}$ \\
\hline $\begin{array}{l}\text { Willingness to } \\
\text { accept }\end{array}$ & $\begin{array}{c}\text { Prevention of } \\
\text { non-point source } \\
\text { pollution of farmland }\end{array}$ & 2009 & $380,000-625,000$ & $61,000-100,000$ & $0.37-0.44$ & $\begin{array}{l}\text { Wuhan City, } \\
\text { Hubei Province, } \\
\text { China }\end{array}$ & Developed & $\begin{array}{c}\text { Cai et al., } 2009 \\
{[40]}\end{array}$ \\
\hline $\begin{array}{l}\text { Willingness to } \\
\text { accept } \\
\text { opportunity cost }\end{array}$ & $\begin{array}{c}\text { Prevention of } \\
\text { non-point source } \\
\text { pollution of farmland }\end{array}$ & 2009 & 629.4-7097.7 & $101.03-1139.23$ & $0.06-0.67$ & $\begin{array}{l}\text { Yixing City, } \\
\text { Jiangsu } \\
\text { Province, China }\end{array}$ & Developed & $\begin{array}{l}\text { Zhang et al., } \\
2017 \text { [41] }\end{array}$ \\
\hline
\end{tabular}




\section{Conclusions}

In the field of non-point source pollution prevention and local poverty reduction, scientifically formulating credible compensation standards is a critical and key step in adjusting the benefits among the environment protectors and the beneficiaries. In the present research, we created a non-point source pollution eco-compensation standard in farmland based on emergy synthesis in an ecological fragile and poor agro-pastoral area in China. The local farmers' willingness to receive eco-compensation and the regional finance situation were also investigated and used as references. The main conclusions are as follows.

1. We proposed a quantification method that considers the ecological economic emergy value of non-point source pollution eco-compensation standard, overcoming the inconsistencies in quantification of the material flow, ecological flow, and economic flow, which create uncertainties in the assessment processes.

2. The agricultural non-point source pollution has gradually intensified in HLBB since 1995. From the perspective of emergy in the agro-pastoral system, $\mathrm{N}_{2} \mathrm{O}$ is the main pollutant that caused the most non-point source pollution from farmland in HLBB from 2010 to 2015, although its physical amount was the largest among the selected seven pollutant source indexes.

3. In HLBB, the optimal eco-compensation strategy is a $20 \%$ reduction in phosphate fertilizer application with a compensation standard of $\$ 379.63 /$ ha/year, which accounts for $2.72 \%$ of GDP in HLBB in 2015. In such poverty-stricken areas, jointly supporting from local finance and central finance are required in the implementation of the eco-compensation.

Author Contributions: The study was designed and performed by Y.G. The data were collected by Z.H., Y.G., and Y.C. The data was analyzed by Z.H. and Y.G. The paper was written by Z.H., Y.G. and L.L. The final checked and revised by Y.G. and H.Z. All authors read and approved the final manuscript.

Funding: This research was financially supported by National Key Research and Development Plan Program of China (2016YFD0800906).

Acknowledgments: The authors sincerely thank editors and all anonymous reviewers for their beneficial suggestions to improve the quality of this article.

Conflicts of Interest: The authors declare no conflict of interest.

\section{Appendix A}

Table A1. The physical amounts of pollutant emissions under current and fertilizer reduction scenarios (kg ha-1/year).

\begin{tabular}{ccccccc}
\hline Fertilizer Reduction Scenario & $\mathbf{N}_{\mathbf{2}} \mathbf{O}$ & $\mathbf{N H}_{\mathbf{3}}$ & $\mathbf{N H}_{\mathbf{3}}-\mathbf{N}$ & $\mathbf{T N}$ & $\mathbf{T P}$ \\
\hline \multicolumn{2}{c}{ Current situation $(2015)$} & 5.97 & 41.80 & 1.85 & 2.92 & 0.98 \\
\hline \multirow{2}{*}{1} & $\mathrm{NPR}$ & 5.55 & 38.88 & 1.23 & 1.95 & 0.65 \\
& $\mathrm{NR}$ & 5.14 & 35.97 & 1.73 & 2.73 & 0.91 \\
& $\mathrm{PR}$ & 5.97 & 41.80 & 1.73 & 2.73 & 0.91 \\
\hline \multirow{2}{*}{2} & $\mathrm{NPR}$ & 5.14 & 35.97 & 1.23 & 1.95 & 0.65 \\
& $\mathrm{NR}$ & 4.31 & 30.14 & 1.73 & 2.73 & 0.91 \\
& $\mathrm{PR}$ & 5.97 & 41.80 & 1.73 & 2.73 & 0.91 \\
\hline \multirow{3}{*}{3} & $\mathrm{NPR}$ & 4.72 & 33.06 & 1.23 & 1.95 & 0.65 \\
& $\mathrm{NR}$ & 3.47 & 24.32 & 1.60 & 2.53 & 0.85 \\
& $\mathrm{PR}$ & 5.97 & 41.80 & 1.73 & 2.73 & 0.91 \\
\hline \multirow{2}{*}{4} & $\mathrm{NPR}$ & 4.31 & 30.14 & 1.23 & 2.92 & 0.65 \\
& $\mathrm{NR}$ & 2.64 & 18.49 & 1.23 & 1.95 & 0.65 \\
& $\mathrm{PR}$ & 5.97 & 41.80 & 1.73 & 2.73 & 0.91 \\
\hline
\end{tabular}


Table A1. Cont.

\begin{tabular}{ccccccc}
\hline Fertilizer Reduction Scenario & $\mathbf{N}_{\mathbf{2}} \mathbf{O}$ & $\mathbf{N H}_{\mathbf{3}}$ & $\mathbf{N H}_{\mathbf{3}}-\mathbf{N}$ & $\mathbf{T N}$ & $\mathbf{T P}$ \\
\hline \multirow{2}{*}{5} & $\mathrm{NPR}$ & 3.89 & 27.23 & 1.23 & 2.92 & 0.65 \\
& $\mathrm{NR}$ & 1.81 & 12.66 & 1.23 & 1.95 & 0.65 \\
$\mathrm{PR}$ & 5.97 & 41.80 & 1.73 & 2.73 & 0.91 \\
\hline
\end{tabular}

Note: NPR: Nitrogen and phosphate fertilizer reduction; NR: Nitrogen fertilizer reduction; PR: Phosphate fertilizer reduction.

Table A2. Physical maize yields under current and fertilizer reduction scenarios ( $\mathrm{kg} \mathrm{ha}^{-1} /$ year).

\begin{tabular}{ccc}
\hline \multicolumn{2}{c}{ Fertilizer Reduction Scenario } & Maize Yield \\
\hline \multicolumn{2}{c}{ Current situation $(2015)$} & $11,538.71$ \\
\hline \multirow{2}{*}{1} & NPR & $10,558.08$ \\
& NR & $10,309.51$ \\
PR & $10,818.37$ \\
\hline \multirow{2}{*}{2} & NPR & 9395.67 \\
& NR & 8748.31 \\
& PR & $10,089.93$ \\
\hline \multirow{3}{*}{3} & NPR & 8051.49 \\
& NR & 6855.11 \\
4 & PR & 9353.39 \\
\hline \multirow{2}{*}{4} & NPR & 6525.53 \\
& NR & 4629.91 \\
PR & 8608.75 \\
\hline \multirow{2}{*}{5} & NPR & 4817.80 \\
& NR & 2072.71 \\
& PR & 7856.01 \\
\hline
\end{tabular}

Table A3. The emergy values of pollutant emissions under current and fertilizer reduction scenarios (seJ/ha/year).

\begin{tabular}{|c|c|c|c|c|c|c|c|}
\hline \multicolumn{2}{|c|}{$\begin{array}{c}\text { Fertilizer Reduction } \\
\text { Scenario }\end{array}$} & $\mathrm{N}_{2} \mathrm{O}$ & $\mathrm{NH}_{3}$ & $\mathrm{NH}_{3}-\mathrm{N}$ & $\mathrm{TN}$ & TP & Sum \\
\hline \multicolumn{2}{|c|}{$\begin{array}{l}\text { Emergy transformity of } \\
\text { pollution }(\mathrm{seJ} / \mathrm{kg})\end{array}$} & $1.13 \times 10^{14}$ & $4.52 \times 10^{11}$ & $5.83 \times 10^{13}$ & $5.85 \times 10^{13}$ & $1.90 \times 10^{14}$ & \\
\hline \multicolumn{2}{|c|}{ Current situation (2015) } & $6.76 \times 10^{14}$ & $1.89 \times 10^{13}$ & $1.08 \times 10^{14}$ & $1.71 \times 10^{14}$ & $1.86 \times 10^{14}$ & $1.16 \times 10^{15}$ \\
\hline \multirow{3}{*}{1} & NPR & $6.29 \times 10^{14}$ & $1.76 \times 10^{13}$ & $7.18 \times 10^{13}$ & $1.14 \times 10^{14}$ & $1.24 \times 10^{14}$ & $9.56 \times 10^{14}$ \\
\hline & NR & $5.82 \times 10^{14}$ & $1.63 \times 10^{13}$ & $1.01 \times 10^{14}$ & $1.59 \times 10^{14}$ & $1.74 \times 10^{14}$ & $1.03 \times 10^{15}$ \\
\hline & PR & $6.76 \times 10^{14}$ & $1.89 \times 10^{13}$ & $1.01 \times 10^{14}$ & $1.59 \times 10^{14}$ & $1.74 \times 10^{14}$ & $1.13 \times 10^{15}$ \\
\hline \multirow{3}{*}{2} & NPR & $5.82 \times 10^{14}$ & $1.63 \times 10^{13}$ & $7.18 \times 10^{13}$ & $1.14 \times 10^{14}$ & $1.24 \times 10^{14}$ & $9.08 \times 10^{14}$ \\
\hline & NR & $4.87 \times 10^{14}$ & $1.36 \times 10^{13}$ & $1.01 \times 10^{14}$ & $1.59 \times 10^{14}$ & $1.74 \times 10^{14}$ & $9.35 \times 10^{14}$ \\
\hline & PR & $6.76 \times 10^{14}$ & $1.89 \times 10^{13}$ & $1.01 \times 10^{14}$ & $1.59 \times 10^{14}$ & $1.74 \times 10^{14}$ & $1.13 \times 10^{15}$ \\
\hline \multirow{3}{*}{3} & NPR & $5.35 \times 10^{14}$ & $1.49 \times 10^{13}$ & $7.18 \times 10^{13}$ & $1.14 \times 10^{14}$ & $1.24 \times 10^{14}$ & $8.59 \times 10^{14}$ \\
\hline & NR & $3.93 \times 10^{14}$ & $1.10 \times 10^{13}$ & $9.34 \times 10^{13}$ & $1.48 \times 10^{14}$ & $1.61 \times 10^{14}$ & $8.07 \times 10^{14}$ \\
\hline & PR & $6.76 \times 10^{14}$ & $1.89 \times 10^{13}$ & $1.01 \times 10^{14}$ & $1.59 \times 10^{14}$ & $1.74 \times 10^{14}$ & $1.13 \times 10^{15}$ \\
\hline \multirow{3}{*}{4} & NPR & $4.87 \times 10^{14}$ & $1.36 \times 10^{13}$ & $7.18 \times 10^{13}$ & $1.71 \times 10^{14}$ & $1.24 \times 10^{14}$ & $8.68 \times 10^{14}$ \\
\hline & NR & $2.99 \times 10^{14}$ & $8.36 \times 10^{12}$ & $7.18 \times 10^{13}$ & $1.14 \times 10^{14}$ & $1.24 \times 10^{14}$ & $6.17 \times 10^{14}$ \\
\hline & PR & $6.76 \times 10^{14}$ & $1.89 \times 10^{13}$ & $1.01 \times 10^{14}$ & $1.59 \times 10^{14}$ & $1.74 \times 10^{14}$ & $1.13 \times 10^{15}$ \\
\hline \multirow{3}{*}{5} & NPR & $4.40 \times 10^{14}$ & $1.23 \times 10^{13}$ & $7.18 \times 10^{13}$ & $1.71 \times 10^{14}$ & $1.24 \times 10^{14}$ & $8.19 \times 10^{14}$ \\
\hline & NR & $2.05 \times 10^{14}$ & $5.72 \times 10^{12}$ & $7.18 \times 10^{13}$ & $1.14 \times 10^{14}$ & $1.24 \times 10^{14}$ & $5.20 \times 10^{14}$ \\
\hline & PR & $6.76 \times 10^{14}$ & $1.89 \times 10^{13}$ & $1.01 \times 10^{14}$ & $1.59 \times 10^{14}$ & $1.74 \times 10^{14}$ & $1.13 \times 10^{15}$ \\
\hline
\end{tabular}


Table A4. The emergy values of maize yields under current and fertilizer reduction scenarios (sej/ha/year).

\begin{tabular}{|c|c|c|}
\hline \multicolumn{2}{|c|}{ Fertilizer Reduction Scenario } & Maize Yield \\
\hline \multicolumn{2}{|c|}{ Emergy transformity of maize (sej/kg) } & $3.04 \times 10^{12}$ \\
\hline \multicolumn{2}{|c|}{ Current situation (2015) (sej) } & $3.51 \times 10^{16}$ \\
\hline \multirow{3}{*}{1} & NPR & $3.21 \times 10^{16}$ \\
\hline & NR & $3.13 \times 10^{16}$ \\
\hline & PR & $3.29 \times 10^{16}$ \\
\hline \multirow{3}{*}{2} & NPR & $2.86 \times 10^{16}$ \\
\hline & NR & $2.66 \times 10^{16}$ \\
\hline & PR & $3.07 \times 10^{16}$ \\
\hline \multirow{3}{*}{3} & NPR & $2.45 \times 10^{16}$ \\
\hline & NR & $2.08 \times 10^{16}$ \\
\hline & PR & $2.84 \times 10^{16}$ \\
\hline \multirow{3}{*}{4} & NPR & $1.98 \times 10^{16}$ \\
\hline & NR & $1.41 \times 10^{16}$ \\
\hline & PR & $2.62 \times 10^{16}$ \\
\hline \multirow{3}{*}{5} & NPR & $1.46 \times 10^{16}$ \\
\hline & NR & $6.30 \times 10^{15}$ \\
\hline & PR & $2.39 \times 10^{16}$ \\
\hline
\end{tabular}

Table A5. Eco-compensation of pollutant emissions based on emergy synthesis (\$/ha/year).

\begin{tabular}{cccccccc}
\hline Fertilizer Reduction Scenario & $\mathbf{N}_{\mathbf{2}} \mathbf{O}$ & $\mathbf{N H}_{\mathbf{3}}$ & $\mathbf{N H}_{\mathbf{3}}-\mathbf{N}$ & $\mathbf{T N}$ & $\mathbf{T P}$ & Sum \\
\hline \multicolumn{2}{c}{ Current situation $(2015)$} & 115.54 & 3.23 & 18.42 & 29.21 & 31.82 & 198.22 \\
\hline \multirow{3}{*}{1} & $\mathrm{NPR}$ & 107.49 & 3.00 & 12.28 & 19.47 & 21.21 & 163.46 \\
& $\mathrm{NR}$ & 99.43 & 2.78 & 17.19 & 27.26 & 29.70 & 176.37 \\
& $\mathrm{PR}$ & 115.54 & 3.23 & 17.19 & 27.26 & 29.70 & 192.93 \\
\hline \multirow{2}{*}{2} & $\mathrm{NPR}$ & 99.43 & 2.78 & 12.28 & 19.47 & 21.21 & 155.18 \\
& $\mathrm{NR}$ & 83.33 & 2.33 & 17.19 & 27.26 & 29.70 & 159.81 \\
& $\mathrm{PR}$ & 115.54 & 3.23 & 17.19 & 27.26 & 29.70 & 192.93 \\
\hline \multirow{3}{*}{3} & $\mathrm{NPR}$ & 91.38 & 2.55 & 12.28 & 19.47 & 21.21 & 146.90 \\
& $\mathrm{NR}$ & 67.22 & 1.88 & 15.97 & 25.31 & 27.58 & 137.96 \\
& $\mathrm{PR}$ & 115.54 & 3.23 & 17.19 & 27.26 & 29.70 & 192.93 \\
\hline \multirow{3}{*}{4} & $\mathrm{NPR}$ & 83.33 & 2.33 & 12.28 & 29.21 & 21.21 & 148.36 \\
& $\mathrm{NR}$ & 51.11 & 1.43 & 12.28 & 19.47 & 21.21 & 105.51 \\
& $\mathrm{PR}$ & 115.54 & 3.23 & 17.19 & 27.26 & 29.70 & 192.93 \\
\hline \multirow{2}{*}{5} & $\mathrm{NPR}$ & 75.27 & 2.10 & 12.28 & 29.21 & 21.21 & 140.08 \\
& $\mathrm{NR}$ & 35.01 & 0.98 & 12.28 & 19.47 & 21.21 & 88.95 \\
& $\mathrm{PR}$ & 115.54 & 3.23 & 17.19 & 27.26 & 29.70 & 192.93 \\
\hline
\end{tabular}


Table A6. Eco-compensation of maize yield loss based on emergy synthesis (\$/ha/year).

\begin{tabular}{ccc}
\hline Fertilizer Reduction Scenario & Maize Yield Loss \\
\hline \multirow{3}{*}{1} & NPR & 544.36 \\
& NR & 660.62 \\
PR & 379.63 \\
\hline \multirow{2}{*}{2} & NPR & 1156.69 \\
& NR & 1488.46 \\
PR & 758.17 \\
\hline \multirow{2}{*}{3} & NPR & 1863.48 \\
& NR & 2494.14 \\
4 & PR & 1140.92 \\
\hline \multirow{3}{*}{4} & NPR & 2655.00 \\
& NR & 3682.93 \\
& PR & 1527.87 \\
\hline \multirow{3}{*}{5} & NPR & 3550.72 \\
& NR & 5028.35 \\
& PR & 1919.04 \\
\hline
\end{tabular}

Table A7. The eco-compensation of agricultural non-point pollution control based on emergy synthesis (\$/ha/year).

\begin{tabular}{cccc}
\hline \multirow{2}{*}{ Scenario } & \multicolumn{3}{c}{ Eco-compensation Standards under Different Reduction Proportions } \\
\cline { 2 - 4 } & $\begin{array}{c}\text { Nitrogen and Phosphate } \\
\text { Fertilizer Reduction } \\
\text { (NPR) }\end{array}$ & $\begin{array}{c}\text { Nitrogen Fertilizer } \\
\text { Reduction } \\
\text { (NR) }\end{array}$ & $\begin{array}{c}\text { Phosphate Fertilizer } \\
\text { Reduction } \\
\text { (PR) }\end{array}$ \\
\hline 1 & 544.36 & 660.62 & 379.63 \\
2 & 1156.69 & 1488.46 & 758.17 \\
3 & 1863.48 & 2494.14 & 1140.92 \\
4 & 2655.00 & 3682.93 & 1527.87 \\
5 & 3550.72 & 5028.35 & 1919.04 \\
\hline
\end{tabular}

\section{References}

1. Weidner, H. Capacity building for ecological modernization: Lessons from cross-national research. Am. Behav. Sci. 2002, 45, 1340-1368. [CrossRef]

2. Mensah, A.M.; Castro, L.C. Sustainable Resource Use \& Sustainable Development: A Contradiction; Center for Development Research, University of Bonn: Bonn, Germany, 2004.

3. Liu, G.H.; Wan, J.; Zhang, H.Y.; Cai, L.J. Eco-Compensation Policies and Mechanisms in China. Rev. Eur. Comp. Int. Environ. Law 2008, 17, 234-242. [CrossRef]

4. Liu, M.C.; Yin, X.; Zheng, Y.; Min, Q.W.; Sun, Y.H.; Fuller, A.M. Standards of ecological compensation for traditional eco-agriculture: Taking rice-fish system in Hani terrace as an example. J. Mt. Sci. 2014, 11, 1049-1059. [CrossRef]

5. Shang, W.X.; Gong, Y.C.; Wang, Z.J.; Stewardson, M.J. Eco-compensation in China: Theory, practices and suggestions for the future. J. Environ. Manag. 2018, 210, 162-170. [CrossRef] [PubMed]

6. Bennett, M.T.; Gong, Y.; Scarpa, R. Hungry birds and angry farmers: Using choice experiments to assess "Eco-compensation" for Coastal Wetlands Protection in China. Ecol. Econ. 2018, 154, 71-87. [CrossRef]

7. Vatn, A.; Bromley, D.W. Choices without prices without apologies. J. Environ. Econ. Manag. 1994, 26, 129-148. [CrossRef]

8. Place, F.; Dewees, P. Policies and incentives for the adoption of improved fallows. Agrofor. Syst. 1999, 47, 323-343. [CrossRef]

9. Rosenthal, G. Selecting target species to evaluate the success of wet grassland restoration. Agric. Ecosyst. Environ. 2003, 98, 227-246. [CrossRef] 
10. Zheng, H.; Robinson, B.E.; Liang, Y.C.; Polasky, S.; Ma, D.C.; Wang, F.C.; Ruckelshaus, M.; Ouyang, Z.Y.; Daily, G.C. Benefits, costs, and livelihood implications of a regional payment for ecosystem service program. Proc. Natl. Acad. Sci. USA 2013, 110, 16681-16686. [CrossRef]

11. Arabomena O., J.; Chirwaa P., W.; Babalolaa F., D. Willingness-to-pay for environmental services provided by trees in core and fringe areas of Benin City, Nigeria. Int. For. Rev. 2019, 21, 23-36. [CrossRef]

12. Rodríguez de Francisco, J.C.; Budds, J.; Boelens, R. Payment for environmental services and unequal resource control in Pimampiro, Ecuador. Soc. Nat. Resour. 2013, 26, 1217-1233. [CrossRef]

13. Hein, L.; Van Koppen, K.; De Groot, R.S.; Van Ierland, E.C. Spatial scales, stakeholders and the valuation of ecosystem services. Ecol. Econ. 2006, 57, 209-228. [CrossRef]

14. Zbinden, S.; Lee, D.R. Paying for environmental services: An analysis of participation in Costa Rica's PSA Program. World. Dev. 2005, 33, 255-272. [CrossRef]

15. Engel, S.; Wunscher, T.; Wunder, S. Determinants of participation in payments for ecosystem service schemes. Tropentag 2010, 9, 14-16.

16. Engel, S.; Pagiola, S.; Wunder, S. Designing payments for environmental services in theory and practice: An overview of the issues. Ecol. Econ. 2008, 65, 663-674. [CrossRef]

17. Moran, D.; McVittie, A.; AllcroftD, J.; Elston, D.A. Quantifying public preferences for agri-environmental policy in Scotland: A comparison of methods. Ecol. Econ. 2007, 63, 42-53. [CrossRef]

18. Pan, J.; Zeng, W.Z.; Zhang, W.K. The willingness to pay for the ecological compensation of Min River Basin-Based on the survey of Chengdu 282 households. Environ. Pollut. 2012, 1, 14-20. [CrossRef]

19. Liu, M.C.; Liu, W.W.; Yang, L.; Jiao, W.J.; He, S.Y.; Min, Q.W. A dynamic eco-compensation standard for Hani Rice Terraces System in southwest China. Ecosyst. Serv. 2019, 36, 100897. [CrossRef]

20. Odum, H.T. Environmental accounting: Emergy and environmental decision making. Child Dev. 1996, 42, 1187-1201.

21. Lan, S.F.; Qin, P.; Lu, H.F. Emergy Analysis on Ecological-Economic Systems; Chemical Industry Press: Beijing, China, 2002; pp. 27-42. (In Chinese)

22. Wu, Z.N.; Guo, X.; Lv, C.M.; Wang, H.L.; Di, D.Y. Study on the quantification method of water pollution ecological compensation standard based on emergy theory. Ecol. Indic. 2018, 92, 189-194. [CrossRef]

23. Guo, W.X.; Fu, Y.C.; Ruan, B.Q.; Ge, H.F.; Zhao, N.N. Agricultural non-point source pollution in the Yongding River Basin. Ecol. Indic. 2014, 36, 254-261. [CrossRef]

24. Guan, X.J.; Hu, C.; Chen, M.Y. An ecological compensation standard based on emergy theory for the Xiao Honghe River Basin. Water Sci. Technol. 2015, 71, 1463-1470. [CrossRef] [PubMed]

25. Fu, Y.C.; Du, X.; Ruan, B.Q.; Liu, L.S. Agro-ecological compensation of watershed based on emergy. Water Sci. Technol. 2017, 76, 2830-2841. [CrossRef]

26. Huang, L.; Xiao, T.; Zhao, Z.Z.; Sun, C.Y.; Liu, J.Y.; Shao, Q.Q.; Fan, J.W.; Wang, J.B. Effects of grassland restoration programs on ecosystems in arid and semiarid China. J. Environ. Manag. 2013, 117, 268-275. [CrossRef] [PubMed]

27. Sun, B.; Zhang, L.X.; Yang, L.Z.; Zhang, F.S.; Norse, D.; Zhu, Z.L. Agricultural non-point source pollution in China: Causes and mitigation measures. Ambio 2012, 41, 370-379. [CrossRef]

28. Zhou, J.; Zhang, F.R.; Xu, Y.; Gao, Y.; Xie, Z. Evaluation of land reclamation and implications of ecological restoration for agro-pastoral ecotone: Case study of Horqin Left Back Banner in China. Chin. Geogr. Sci. 2017, 27, 772-783. [CrossRef]

29. Ulgiati, S.; Odum, H.T.; Bastianoni, S. Emergy use, environmental loading and sustainability an emergy analysis of Italy. Ecol. Model. 1994, 73, 215-268. [CrossRef]

30. Brown, M.T.; Brandt-Williams, S.L.; Tilley, D.; Ulgiati, S. Emergy Synthesis 1: Theory and Application of the Emergy Methodology; University of Florida: Gainesville, FL, USA, 2000; pp. 1-14.

31. Zhang, Y.; Yang, Z.F.; Yu, X.Y. Evaluation of urban metabolism based on emergy synthesis: A case study for Beijing (China). Ecol. Model. 2009, 220, 1690-1696. [CrossRef]

32. Brown, M.T.; Ulgiati, S. Updated evaluation of exergy and emergy driving the geobiosphere: A review and refinement of the emergy baseline. Ecol. Model. 2010, 221, 2501-2508. [CrossRef]

33. Zhang, T.H.; Cui, J.Y.; Zhao, H.L.; Zhao, X.Y.; Li, Y.L. Effect of the factors of soil water content and fertilizers on yield of spring corn at sandy cropland, in Horqin sand land. J. Desert Res. 2000, 1, 59-62.

34. Milder, J.C.; Scherr, S.J.; Bracer, C. Trends and future potential of payment for ecosystem services to alleviate rural poverty in developing countries. Ecol. Soc. 2010, 15, 4. [CrossRef] 
35. Price Division of China National Development and Reform Commission. National Agricultural Product Cost-Benefit Data Compilation; China Statistic Press: Beijing, China, 2016.

36. Kemkes, R.J.; Farley, J.; Koliba, C.J. Determining when payments are an effective policy approach to ecosystem service provision. Ecol. Econ. 2010, 69, 2069-2074. [CrossRef]

37. Yin, K.; Xiao, Y. Economic compensation criteria of eco-fallow based on non-market value of cultivated land in water-level fluctuation zone of Three Gorges Reservoir Area. Bull. Soil Water Conserv. 2017, 37, 239-246. (In Chinese)

38. Yu, L.L.; Gai, Y.Y. Ecological compensation based on farmers' willingness: A case study of Jingsan County in Hubei Province, China. Chin. J. Appl. Ecol. 2015, 26, 215-223. (In Chinese)

39. Mao, D.H.; Hu, G.W.; Liu, H.J.; Li, Z.Z.; Li, Z.L.; Tian, Z.Z. Ecological compensation standard in Dongting Lake region of returning cropland to lake based on emergy analysis. Chin. J. Appl. Ecol. 2014, 25, 525-532. (In Chinese)

40. Cai, Y.Y.; Yu, L.L. Ecological compensation for agricultural land in the key development area of Wuhan. Resour. Sci. 2014, 36, 1660-1669. (In Chinese)

41. Zhang, Y.; Ji, Y.; Zhou, Y.; Sun, H. Ecological Compensation Standard for Non-Point Pollution from Farmland. Probl. Ekorozw. 2017, 12, 139-146.

(C) 2019 by the authors. Licensee MDPI, Basel, Switzerland. This article is an open access article distributed under the terms and conditions of the Creative Commons Attribution (CC BY) license (http://creativecommons.org/licenses/by/4.0/). 